\title{
A Systematic Study on Knoevenagel Reaction and Nazarov Cyclization of Less Reactive Carbonyl Compounds Using Rare Earth Triflates and Its Applications
}

\author{
A. Ilangovan*, S. Muralidharan, and S. Maruthamuthu ${ }^{\dagger}$ \\ School of Chemistry, Bharathidasan University, Tiruchirappalli - 620024, India. \\ *E-mail: ilangovanbdu@yahoo.com,ilangovana@yahoo.co.uk \\ ${ }^{\dagger}$ Corrosion Protection Division, Central Electro Chemical Research Institute, Karaikudi-630 006, India
}

(Received June 29, 2011; Accepted October 17, 2011)

\begin{abstract}
A systematic study of Knoevenagel reaction and Nazarov cyclization was made on variety of less reactive carbonyl compounds such as $\beta$-ketoesters, 1,3-diketones and cyclic active methylene compounds using $\mathrm{Yb}(\mathrm{OTf})_{3}$ as the catalyst. Recycling study confirms reusability of the catalyst without much loss of activity.
\end{abstract}

Key words: Knoevenagel Reaction, Nazarov cyclization, Yetterbium triflate, 1,3-diketones, Ethyl acetoacetate

Highly substituted $\alpha, \beta$-unsaturated olefins obtained via Knoevenagel condensation are key intermediates for various reactions and have been extensively used in the synthesis of valuable compounds. ${ }^{1-4}$ Identification of diethylamine as a catalyst, first by Knoevenagel, ${ }^{5}$ paved way for the development of a large number catalysts, ${ }^{6-18}$ and conditions. ${ }^{19-28}$ Review of literature shows that compared to large number of bases as catalysts, Lewis acid (LA) catalysts known for Knoevenagel condensation are only limited. $\mathrm{Mg}\left(\mathrm{ClO}_{4}\right)_{2},{ }^{18} \mathrm{LaCl}_{3},{ }^{29} \mathrm{NbCl}_{5},{ }^{30} \mathrm{TiCl}_{4},{ }^{31,32} \mathrm{ZnCl}_{2},{ }^{33}$ and $\mathrm{MgBr}_{2}{ }^{34}$ are known as LA catalysts. Some of these LAs need to be used in more than stoichiometric quantity ${ }^{35}$ and catalyst like $\mathrm{Mg}\left(\mathrm{ClO}_{4}\right)_{2}$ needs $\mathrm{MgSO}_{4}$ as additive. ${ }^{18}$ The presence of adventitious water as well as water generated during the course of the reaction generally degrades some of these conventional LAs, and renders it non reusable one and leads to generation of pollutants. In almost all of the LA mediated Knoevenagel condensations, only highly reactive carbonyl compounds such as malanonitrile, cyanoacetates and malonates are used as substrates. $\mathrm{Mg}\left(\mathrm{ClO}_{4}\right)_{2}$, a potential explosive material, has been used as LA for the reaction on less reactive carbonyl compounds such as $\beta$ ketoesters and 1,3-diketones. ${ }^{18}$

Indanone ring systems is an important building block for the synthesis of biologically active compounds. ${ }^{36} \mathrm{LA}$ catalysts such as $\mathrm{Sc}(\mathrm{OTf})_{3}-\mathrm{LiClO}_{4},{ }^{37} \mathrm{SnCl}_{4}{ }^{38} \mathrm{AlCl}_{3}-N$ fluorobenzenesulfonamide ${ }^{39}$ and $\mathrm{Cu}(\mathrm{OTf})_{3}-N$-fluorobenzenesulfonamide $^{40}$ are known to catalyse Knoevenagel condensation followed Nazarov cyclization between less reactive alkyl benzoylacetate and an aromatic aldehyde to give the indanone ring system and its derivatives. However, there are drawbacks such as the use of additives and more than stociometric quantity of the reagent. This suggests that there is a need for the development of novel LA catalysts which could work on less reactive carbonyl compounds.

Lanthanide triflates, $\left(\operatorname{Ln}(\mathrm{OTf})_{3}\right)^{41,42}$ are new generation, water compatible green LAs which can be recovered almost quantitatively and reused without much loss of activity. Based on our previous experience ${ }^{43-45}$ we feel that the hard Lewis acidic lanthanide triflates must be useful for Knoevenagel reaction on less reactive carbonyl compounds. Thus we observe successful condensation of 2nitrobenzaldehyde (1e) as well as 2-chlorobenzaldehyde (1f) with ethyl acetoacetate (6a), in the presence of $\mathrm{Yb}(\mathrm{OTf})_{3}$ to get alkylidene $\beta$-ketoesters $\mathbf{7 c}$ and $\mathbf{7 d}$ respectively, which are useful intermediates for the synthesis of calcium channel blockers amlodipene and nifedipine (Table 3).

During the course of this study we noticed that there is a short report on the use of $\mathrm{Yb}(\mathrm{OTf})_{3}$ as a catalyst for Knoevenagel reaction. ${ }^{46}$ However, the study involves only two highly reactive carbonyl compounds, malanonitrile and ethyl cyanoacetate, and among the various lanthanide triflates, only $\mathrm{Yb}(\mathrm{OTf})_{3}$ was examined as the catalyst. Similarly, $\mathrm{Yb}(\mathrm{OTf})_{3}$ was used in coupling reaction between alkynes and aldehydes to give trans- $\alpha, \beta$-enones ${ }^{47}$ and in coupling of 8-hydroxyquinoline with aldehyde for the synthesis of alkaloids. ${ }^{48}$ However, there was no systematic study on using $\mathrm{Yb}(\mathrm{OTf})_{3}$ as a catalyst for Knoeve- 
Table 1. Selection of rare earth triflate for Knoevenagel reaction

\begin{tabular}{|c|c|c|c|}
\hline S. No & Catalyst & Yield (\%) & Time (hr) \\
\hline 1 & $\mathrm{Nd}(\mathrm{OTf})_{3}$ & 67 & 12 \\
\hline 2 & $\operatorname{Sm}(\mathrm{OTf})_{3}$ & 72 & 10 \\
\hline 3 & $\mathrm{Gd}(\mathrm{OTf})_{3}$ & 53 & 11 \\
\hline 4 & $\mathrm{Yb}(\mathrm{OTf})_{3}{ }^{\mathrm{a}}$ & $94,94,93,93$ & 06 \\
\hline 5 & $\mathrm{Yb}(\mathrm{OTf})_{3}{ }^{\mathrm{b}}$ & 94 & 11 \\
\hline
\end{tabular}

$\overline{{ }^{a}}$ The reqaction was repeated using recovered catalyst for second, third and fourth time

${ }^{\mathrm{b}} 5 \mathrm{~mol} \%$ of catalyst was used

nagel adduct formation between less reactive carbonyl compounds and aromatic aldehydes of varied reactivity. To the best of our knowledge, there is no report on the use of $\mathrm{Yb}(\mathrm{OTf})_{3}$ as a catalyst for Nazarov cyclization. Here in we report our results.

To identify the best catalyst, Knoevenagel condensation was studied between a more reactive carbonyl compound, ethyl cyanoacetate (2b) and 4-methoxy benzaldehyde (1b) using different lanthanide trifltes, $\mathrm{Nd}(\mathrm{OTf})_{3}, \mathrm{Sm}(\mathrm{OTf})_{3}$, $\mathrm{Gd}(\mathrm{OTf})_{3}$ and $\mathrm{Yb}(\mathrm{OTf})_{3}$. This covers low to high Lewis acidity range of lanthanide triflates. The results are summarized in Table 1 . With $\mathrm{Yb}(\mathrm{OTf})_{3}(10 \mathrm{~mol} \%)$ in toluene, at $110^{\circ} \mathrm{C}$, the adduct $3 \mathbf{d}$ was obtained, after $12 \mathrm{~h}$, only in traces. With benzene, $\mathrm{CH}_{2} \mathrm{Cl}_{2}, \mathrm{CH}_{3} \mathrm{CN}$ and $\mathrm{CH}_{3} \mathrm{NO}_{2}$ as the solvent, the yield was not impressive.

However, when the reaction was carried out at $80-85^{\circ} \mathrm{C}$, without any solvent, for $6 \mathrm{~h}$, the desired adduct $\mathbf{3 d}$ was obtained in good yield (Table 1). Among the catalysts, $\mathrm{Yb}(\mathrm{OTf})_{3}$ gave high yield of the product in short time. With $5 \mathrm{~mol} \%$ of the catalyst it took more time for completion (11 h, entry 5). Thus the use of $\mathrm{Yb}(\mathrm{OTf})_{3}(10$ mol\%) as the catalyst at $80-85{ }^{\circ} \mathrm{C}$, without solvent was identified as the best condition for further study. In order to check reusability of the catalyst, it was recovered from aqueous workup and reused for the same reaction. The catalyst could be recovered up to $98 \%$ and the product yield was almost the same for the second (94\%), third $(93 \%)$ and fourth (93\%) time. To establish the generality and scope of the method, further study on different active methylene compounds was carried out.

Excellent yield to very high yield of the Knoevenagel adduct was obtained on reaction of malanonitrile (2a), ethyl cyanoacetate (2b) with aromatic aldehydes (1a-f) containing electron donating as well as withdrawing substituents (entry 1-8, Table 2). In case of diethyl malonate
Table 2. $\mathrm{Yb}(\mathrm{OTf})_{3}$ Catalysed Knoevenagel Reaction

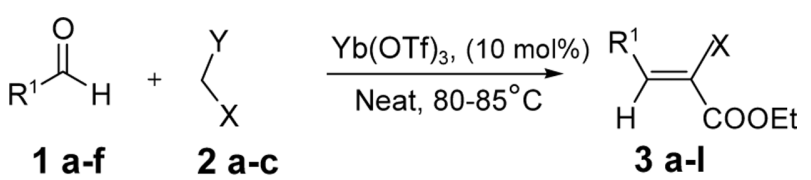

$2 a X=Y=C N, 2 b X=C N, Y=$ COOEt, $2 c X=Y=$ COOEt

\begin{tabular}{ccccccc}
\hline Entry & $\begin{array}{c}\text { Starting Material } \\
\mathrm{R}^{1}\end{array}$ & $\mathrm{X}$ & $\mathrm{Y}$ & $\begin{array}{c}\text { Prod- } \\
\text { uct }\end{array}$ & $\begin{array}{c}\text { Time } \\
(\mathrm{h})\end{array}$ & $\begin{array}{c}\text { Yield } \\
(\mathbf{\%})\end{array}$ \\
\hline 1 & $4-\mathrm{OMe}-\mathrm{C}_{6} \mathrm{H}_{4}(\mathbf{1 b})$ & $\mathrm{CN}$ & $\mathrm{CN}$ & $\mathbf{3 a}$ & 2 & 98 \\
2 & $4-\mathrm{NO}_{2}-\mathrm{C}_{6} \mathrm{H}_{4}(\mathbf{1 d})$ & $\mathrm{CN}$ & $\mathrm{CN}$ & $\mathbf{3 b}$ & 2 & 98 \\
3 & $-\mathrm{C}_{6} \mathrm{H}_{5}(\mathbf{1 a})$ & $\mathrm{CN}$ & $\mathrm{COOEt}$ & $\mathbf{3 c}$ & 4.5 & 95 \\
4 & $4-\mathrm{Oe}-\mathrm{C}_{6} \mathrm{H}_{4}(\mathbf{1 b})$ & $\mathrm{CN}$ & $\mathrm{COOEt}$ & $\mathbf{3 d}$ & 6 & 94 \\
5 & $4-\mathrm{OH}-\mathrm{C}_{6} \mathrm{H}_{4}(\mathbf{1 c})$ & $\mathrm{CN}$ & $\mathrm{COOEt}$ & $\mathbf{3 e}$ & 8.5 & 95 \\
6 & $4-\mathrm{NO}_{2}-\mathrm{C}_{6} \mathrm{H}_{4}(\mathbf{1 d})$ & $\mathrm{CN}$ & $\mathrm{COOEt}$ & $\mathbf{3 f}$ & 10 & 92 \\
7 & $2-\mathrm{NO}_{2}-\mathrm{C}_{6} \mathrm{H}_{4}(\mathbf{1 e})$ & $\mathrm{CN}$ & $\mathrm{COOEt}$ & $\mathbf{3 g}$ & 25 & 92 \\
8 & $2-\mathrm{Cl}_{6}-\mathrm{C}_{6} \mathrm{H}_{4}(\mathbf{1 f})$ & $\mathrm{CN}$ & $\mathrm{COOEt}$ & $\mathbf{3 h}$ & 12 & 85 \\
9 & $4-\mathrm{OMe}_{-}-\mathrm{C}_{6} \mathrm{H}_{4}(\mathbf{1 b})$ & $\mathrm{COOEt}$ & $\mathrm{COOEt}$ & $\mathbf{3 i}$ & 6 & 84 \\
10 & $4-\mathrm{NO}_{2}-\mathrm{C}_{6} \mathrm{H}_{4}(\mathbf{1 d})$ & $\mathrm{COOEt}$ & $\mathrm{COOEt}$ & $\mathbf{3 j}$ & 30 & 80 \\
11 & $2-\mathrm{NO}_{2}-\mathrm{C}_{6} \mathrm{H}_{4}(\mathbf{1 e})$ & $\mathrm{COOEt}$ & $\mathrm{COOEt}$ & $\mathbf{3 k}$ & 24 & 93 \\
12 & $2-\mathrm{Cl}_{-}-\mathrm{C}_{6} \mathrm{H}_{4}(\mathbf{1 f})$ & COOEt & COOEt & $\mathbf{3 1}$ & 7 & 91 \\
\hline
\end{tabular}

'Yiled based on $25 \%$ recovered stating material

(2c), aromatic aldehydes containing electron donating 4$\mathrm{OMe}$ and 2-Cl substituent (entry 9 and 12) reacted fast compared to electron withdrawing 4- $\mathrm{NO}_{2}$ and $2-\mathrm{NO}_{2}$ (entry 10 and 11) substituent. Overall the product yield was high. Comparison of reaction time between malononitrile (2a, 2 h) ethyl cyanoacetates (2b, $10 \mathrm{~h}$ ) and diethyl malonate $(\mathbf{2 c}, 30 \mathrm{~h})$ especially, towards $4-\mathrm{NO}_{2}$ benzaldehyde (entry 2, 6 and 10) clearly shows that compound 2a is more reactive under Knoevenagel reaction conditions. Comparison of reaction time $6 \mathrm{~h}$ and $30 \mathrm{~h}$ for $\mathbf{1 b}$ and $\mathbf{1 d}$ (entry 9 and 10) respectively clearly shows that the aldehydes with electron donating substituent get activated easily by $\mathrm{Yb}(\mathrm{OTf})_{3}$ compared to electron withdrawing substituent. Only a single geometrical isomer was obtained.

As a part of exploiting this methodology towards the synthesis of some biologically active compounds we carried out formal synthesis of antibacterial agent, trimethoprim (Scheme 1). Reaction of 3,4,5-trimethoxybenzaldehyde (1h) and ethyl cyano acetate (2b) gave the adduct $\mathbf{3 m}$ in quantitative yield. Compound $\mathbf{3 m}$ on reduction with Hantzch ester in the presence of silica gel, in toluene led to saturation of double bond and the product $\mathbf{4}$ was condensed with guanidine ${ }^{49-51}$ by literature procedure to get trimethoprim 5. This is an easy and convenient method for the preparation of Trimethoprim. ${ }^{29,49-51}$

Having got good yield of Knovenagel adduct with highly reactive carbonyl compounds, we turned our attention towards less reactive carbonyl compounds such as 


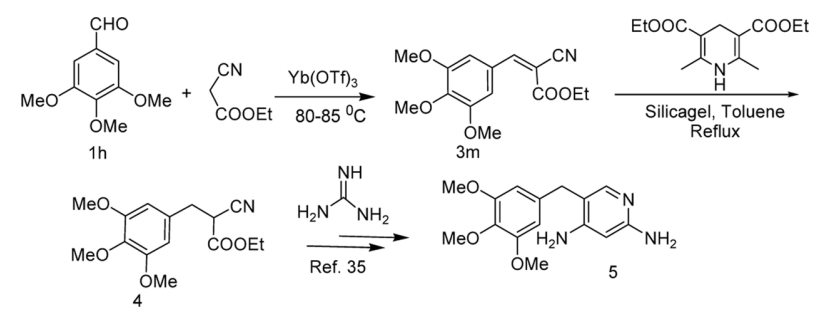

Scheme 1. Synthesis of Triemthoprim.

ethyl acetoacetate (6a) and acetyl acetone (6b). Gratifyingly, the reaction between ethyl acetoacetate (6b) and 2$\mathrm{NO}_{2}$ (1e) benzaldehyde took place readily to give products $7 \mathbf{b}$ respectively in very good yield (entry 2 , Table 3 ). However aldehyde with 4- $\mathrm{NO}_{2}$ (1d) and 2-Cl (1f) substituent reacted only slowly and the reaction was stopped after $15 \mathrm{~h}$.

Geometrical isomers were formed in case of condensation between ethyl acetoacetate $(\mathbf{6 b})$ and aromatic aldehydes. The reaction between ethyl acetoacetate (6a) and 4- $\mathrm{NO}_{2}$-benzaldehyde (1d) gave product 7a containing a mixture of $E: Z$ geometrical isomers in the ratio 6:1. However, 2- $\mathrm{NO}_{2}$-benzaldehyde (1e) and 2-Cl-benzaldehyde (1f) gave products $7 \mathbf{b}$ and $7 \mathbf{c}$ containing $E: Z$ isomers in the ratio 5:5. Compound which shows lower $\delta$ value for $\mathrm{COCH}_{3}$ protons were assigned as $E$ isomer, where $\mathrm{COOC}_{2} \mathrm{H}_{5}$ is trans to the aromatic ring and the other compound as $Z$ isomer. The lower $\delta$ value for $\mathrm{COCH}_{3}$ protons could be attributed to the effective shielding by benzene ring which is positioned cis to $\mathrm{COCH}_{3}$ group. With acetyl acetone (6b) and 4-OMe benzaldehyde (1b), Knoevenagel adduct 7d was obtained in good yield. However, in case of 4$\mathrm{NO}_{2}$-benzaldehyde (1d) containing strong electron withdrawing substituent, the reaction was slow. This observation testifies that $\mathrm{Yb}(\mathrm{OTf})_{3}$ can even catalyse Knoevenagel reaction on less reactive active methylene compounds such as $\beta$-keto esters and 1,3-diketo compounds.
It is interesting to note that with the carbonyl compounds such as ethyl cyanoacetate (2b), diethyl malonate (2c) and ethyl acetoacetate (6a), the 2-nitro benzaldehyde (entry 7 and 11 in Table 2 and entry 2 in Table 3 ) gave high yield of the desired product, despite taking long reaction time. However, this is not the case with aromatic aldehydes substituted with similar electron withdrawing, 4$\mathrm{NO}_{2}$ or $2-\mathrm{Cl}$, substituents (entry $6,8,10,12$, Table 2 and entry 1 Table 3 ). This shows that the presence of $2-\mathrm{NO}_{2}$ group adjacent to aldehyde must be helpful in forming a complex with $\mathrm{Yb}(\mathrm{OTf})_{3}$ and activation of the aldehyde group. The slow reaction rate may be due to, the lone pair of electrons from nitro group oxygen and the aldehyde oxygen forming a chelated complexes with $\mathrm{Yb}(\mathrm{OTf})_{3}$. Comparison of previous reports on Knoevenagel reaction reveals that in general under Lewis acid catalyzed conditions $^{9,18,52}$ aromatic aldehydes substituted with electron donating substituents react readily where as reverse is true with basic compounds as catalysts. ${ }^{8,17}$

With a less reactive carbonyl compound, ethyl benzoylacetate, aromatic aldehydes underwent Knoevenagel condensation followed by cyclization in a tandem Nazarov reaction to give indanone ring system in a one pot procedure (entry 1-4, Table 4). Benzaldehyde (1a, entry 1) and $4-\mathrm{NO}_{2}$ benzaldehyde (1d, entry 3 ) gave the cyclized indanones (10a and 10c) as the only product in very good yield. However, 4-OMe and 2- $\mathrm{NO}_{2}$ benzaldehyde (entry 2 and 4) gave the uncyclized benzyledene $\beta$-keto esters (9b and $9 d$ ) in addition to the cyclized product. Formation of the cyclized product $10 \mathrm{~d}$ could be identified from the ${ }^{1} \mathrm{H}-$ NMR spectral data however, it could not be separated from the unidentified products formed. The four possible isomers formed in the reaction were not separated in our hands on purification by silica gel column chromatography.

Table 3. $\mathrm{Yb}(\mathrm{OTf})_{3}$ Catalysed Knoevenagel condensation of less reactive active methylebne cpompounds

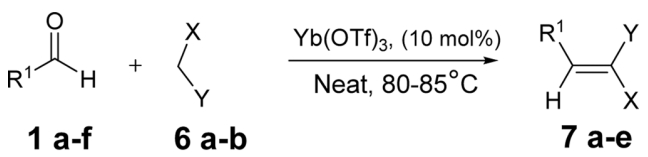

$6 a \mathrm{X}=\mathrm{COCH}_{3}, \mathrm{Y}=\mathrm{COOEt}, 6 \mathrm{~b} \mathrm{X}=\mathrm{Y}=\mathrm{COCH}_{3}$

\begin{tabular}{|c|c|c|c|c|c|c|c|}
\hline Entry & Starting Material $\mathrm{R}_{1}$ & $\mathrm{X}$ & $\bar{Y}$ & Product & Time (h) & Yield (\%) & E/Z ratio \\
\hline 1 & $4-\mathrm{NO}_{2}-\mathrm{C}_{6} \mathrm{H}_{4}(1 \mathrm{~d})$ & $\mathrm{COCH}_{3}$ & COOEt & $7 a$ & 15 & $67^{\mathrm{i}}$ & $6 / 1$ \\
\hline 2 & $2-\mathrm{NO}_{2}-\mathrm{C}_{6} \mathrm{H}_{4}(\mathbf{1 e})$ & $\mathrm{COCH}_{3}$ & COOEt & $7 b$ & 15 & 76 & $5 / 5$ \\
\hline 3 & $2-\mathrm{Cl}-\mathrm{C}_{6} \mathrm{H}_{4}(\mathbf{1 f})$ & $\mathrm{COCH}_{3}$ & COOEt & $7 c$ & 15 & $57^{\mathrm{ii}}$ & $5 / 5$ \\
\hline 4 & $4-\mathrm{OMe}-\mathrm{C}_{6} \mathrm{H}_{4}(\mathbf{1 b})$ & $\mathrm{COCH}_{3}$ & $\mathrm{COCH}_{3}$ & $7 d$ & 18 & $50^{\mathrm{iii}}$ & - \\
\hline 5 & $4-\mathrm{NO}_{2}-\mathrm{C}_{6} \mathrm{H}_{4}(1 \mathrm{~d})$ & $\mathrm{COCH}_{3}$ & $\mathrm{COCH}_{3}$ & $7 e$ & 18 & $34^{\mathrm{iv}}$ & - \\
\hline
\end{tabular}

Yield based on 55\%, 40\%, 40\% and 60\% starting material recovered from i, ii, iii and iv respectively. 
Table 4. $\mathrm{Yb}(\mathrm{OTf})_{3}$ Catalysed Nazarov cyclisation Reaction

\begin{tabular}{ccccc} 
Entry & Starting Material & Time & Isolated & Isolated \\
& $\mathrm{R}$ & Yh) & Yield (\%) & Yield (\%) \\
\hline 1 & $\mathrm{C}_{6} \mathrm{H}_{5}(\mathbf{1 a})$ & 24 & nil (9a) & $88(\mathbf{1 0 a})$ \\
2 & $4-\mathrm{OMe}_{2} \mathrm{C}_{6} \mathrm{H}_{4}(\mathbf{1 b})$ & 24 & $41(\mathbf{9 b})$ & $59(\mathbf{1 0 b})$ \\
3 & $4-\mathrm{NO}_{2}-\mathrm{C}_{6} \mathrm{H}_{4}(\mathbf{1 d})$ & 24 & nil (9c) & $75(\mathbf{1 0 c})$ \\
4 & $2-\mathrm{NO}_{2}-\mathrm{C}_{6} \mathrm{H}_{4}(\mathbf{1 e})$ & 7.5 & $46(\mathbf{9 d})$ & $(\mathbf{1 0 d})$ \\
\hline
\end{tabular}

${ }^{\mathrm{a}} \mathrm{A}$ mixture of steroisomers along with the uidentified products was obtained

Unlike the conventional Lewis acids, $\mathrm{Yb}(\mathrm{OTf})_{3}$ is known to be active even in the presence of Lewis basic amines and nitrogen heterocycles. Barbituric acid, a nitrogen heterocycle with active methylene carbon, underwent facile reaction with aldehydes in the presence of $\mathrm{Yb}(\mathrm{OTf})_{3}$ to give the condensation adducts in very high yield. Both, electron donating as well as electron withdrawing aldehydes gave products in high yield (entry 1-3, Table 5). With yet another cyclic active methylene compound, Meldrums acid, the cyclization product was obtained in moderate yield.

Based on the above observations a tentative mechanism

Table 5. $\mathrm{Yb}(\mathrm{OTf})_{3}$ catalysed Knoevenagel condensation of cyclic activemethylene compounds
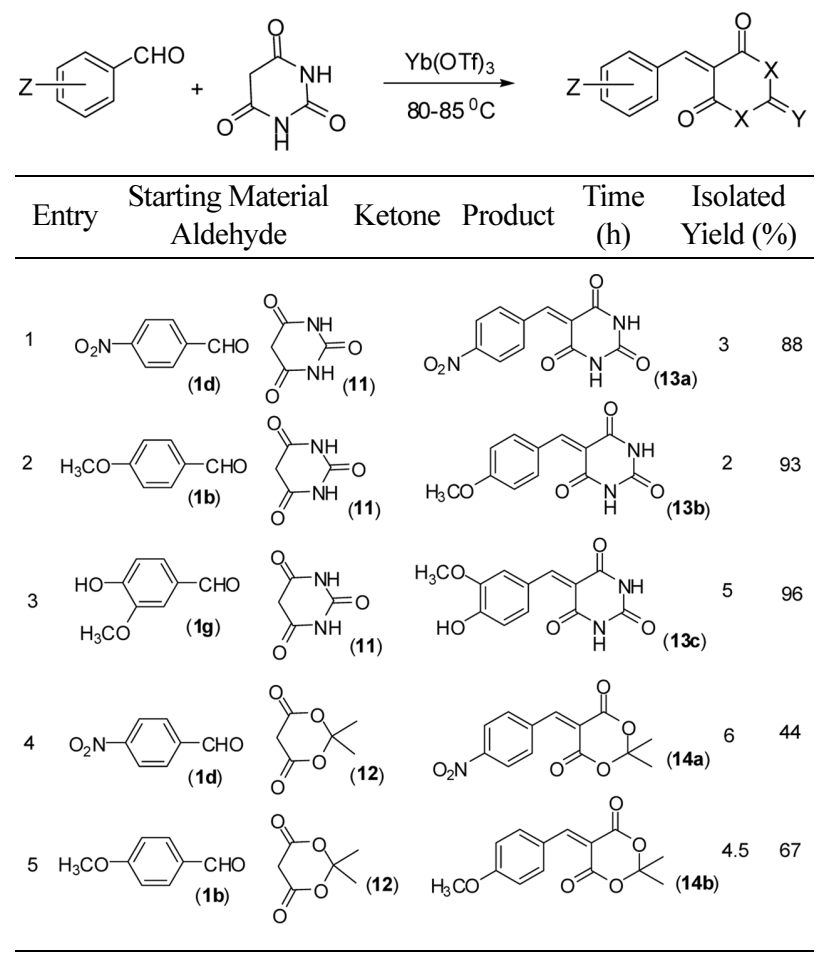

is proposed as given below. The reactivity pattern of aromatic aldehyde indicates that the Lewis acid catalyst forms a complex with the aldehyde group first, followed by which the nucleophilic attack by active methylene should take place on the aldehyde carbon.

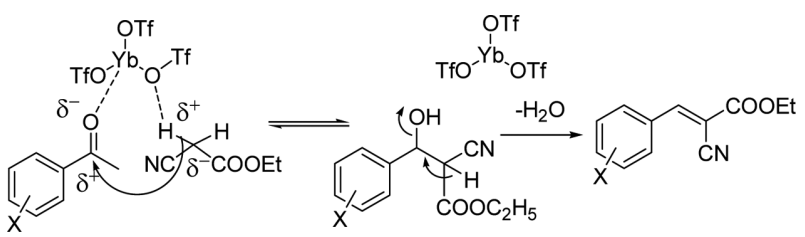

In case of the $\beta$-keto ester and $\beta$-diketones, the enol form is expected to undergo condensation in the following manner.

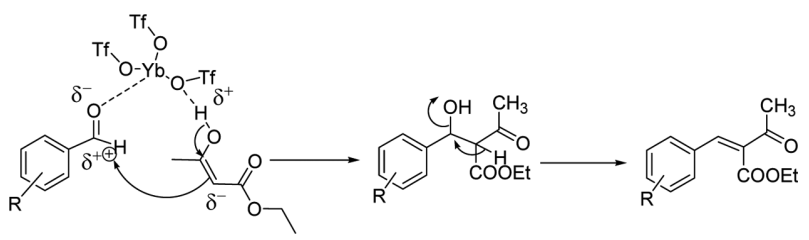

In conclusion, we have established $\mathrm{Yb}(\mathrm{OTf})_{3}(10 \mathrm{~mol}$ $\%$ ) as an effective catalyst for Knoevenagel reaction of several less reactive carbonyl compounds such as $\beta$-keto esters, 1,3-diketo compound and cyclic active methylene compounds. The catalyst was also useful for the Nazarov cylization on ethyl benzoylacetate. For all the reactions no special care was taken to exclude moisture, no solvent was used and simple workup procedure was followed. The catalyst can be recovered and reused without much loss of activity. All these features make this method an attractive Lewis acid catalyst for Knoevenagel condensation as well as Nazarov cyclization of less reactive carbonyl compounds.

\section{EXPERIMENTAL}

All yields reported were based on isolated compounds. TLC separations were carried out on silica gel plates with UV indicator from Aldrich; visualization was by UV fluorescence or by staining with iodine vapor. IR spectra were recorded on a FT-IR Bruker Vector 22 Infrared spectrophotometer using $\mathrm{KBr}$ disks. NMR spectra were recorded on FT-NMR Bruker 400/200 MHz spectrometer as $\mathrm{CDCl}_{3}$ solutions with TMS as internal reference.

General Experimental Procedure for the Synthesis of Substituted Alkenes

To a mixture of an aromatic aldehyde $(5.0 \mathrm{mmol})$ and active methylene compound (5.5 mmol), $\mathrm{Yb}(\mathrm{OTf})_{3}(0.5$ $\mathrm{mmol}$ ) was added and the resulting reaction mixture was 
heated at $80-85^{\circ} \mathrm{C}$ in an oil bath for required time. The progress of the reaction was monitored by thin layer chromatography (TLC, silica gel, hexane: ethyl acetate, 8:2). After completion of the reaction, the reaction mixture was diluted by adding ethyl acetate $(10 \mathrm{~mL})$ and washed with water $(2 \times 5 \mathrm{~mL})$ and brine solution $(5 \mathrm{~mL})$. The organic layer was dried $\left(\mathrm{Na}_{2} \mathrm{SO}_{4}\right)$ and concentrated under reduced pressure. The residue was purified by column chromatography (silica gel, hexane-EtOAc, 8.5:1.5) to afford the substituted olefin in very good yield. All the new products obtained were fully characterized by spectroscopic methods such as IR, ${ }^{1} \mathrm{H}$ NMR, ${ }^{13} \mathrm{C}$ NMR and mass spectroscopy. If the compound is already known in the literature, $\mathrm{IR}$, and ${ }^{1} \mathrm{H}$ NMR values are given, compared with the spectral data already known, and a suitable reference is also mentioned.

\section{2-(4-Methoxybenzylidene)malononitrile (3a)}

The reaction was carried out according to the general experimental procedure using 4-methoxybenzaldehyde (250 $\mathrm{mg}, 1.836 \mathrm{mmol})$, malononitrile (145 mg, $2.197 \mathrm{mmol})$ and $\mathrm{Yb}(\mathrm{OTf})_{3}(114 \mathrm{mg}, 0.184 \mathrm{mmol})$. Conditions: $80-85^{\circ} \mathrm{C}$, $2 \mathrm{~h}$. The title compound 3a was obtained (330 mg, 98\%) as a solid, mp $114-116^{\circ} \mathrm{C}$. The spectral data for the compound 3a was in agreement with the values already reported in the literature.

${ }^{1} \mathrm{H}$ NMR (400 MHz, DMSO) d 3.88 (s, 3H, - $\mathrm{OCH}_{3}$ ), $7.19(\mathrm{~m}, 2 \mathrm{H}, \mathrm{ArH}), 7.97(\mathrm{~m}, 2 \mathrm{H}, \mathrm{ArH})$ and $8.40(\mathrm{~s}, 1 \mathrm{H}$, $\mathrm{ArCH}=)$. IR (KBr) 2224, 1605, 1571, 1513, 1370, 1319, $1279,1185,1022,834 \mathrm{~cm}^{-1}$.

\section{2-(4-Methoxy-benzylidene)-malonic acid diethyl ester} (3i)

The reaction was carried out according to the general procedure using 4-methoxy benzaldehyde ( $100 \mathrm{mg}, 0.735$ mmol), diethyl malonate $(129 \mathrm{mg}, 0.808 \mathrm{mmol})$ and $\mathrm{Yb}(\mathrm{OTf})_{3}$ (52 mg, $0.074 \mathrm{mmol}$ ) conditions: $80-85^{\circ} \mathrm{C}, 6 \mathrm{~h}$. The title compound $3 \mathbf{i}$ was obtained $(171 \mathrm{mg}, 84 \%$ ) as an oily mass. The spectral data of the compound $\mathbf{3 i}$ was in agreement with the values reported in the literature.

${ }^{1} \mathrm{H}$ NMR $\left(400 \mathrm{MHz}, \mathrm{CDCl}_{3}\right) \delta 1.20(\mathrm{t}, J=7.2 \mathrm{~Hz}, 3 \mathrm{H}$, $\left.-\mathrm{CH}_{2} \mathrm{CH}_{3}\right), 1.25$ (t, $\left.J=7.2 \mathrm{~Hz}, 3 \mathrm{H},-\mathrm{CH}_{2} \mathrm{CH}_{3}\right), 3.44$ (s, $3 \mathrm{H}$, $\left.-\mathrm{OCH}_{3}\right), 4.26\left(\mathrm{~m}, J=7.2,16.4 \mathrm{~Hz}, 4 \mathrm{H},-\mathrm{CH}_{2} \mathrm{CH}_{3}\right), 7.49$ (m, 4H, $\mathrm{ArH}), 7.72$ (s, 1H, $\mathrm{ArCH}=)$. IR (KBr) 2982, 1723, $1628,1448,1375,1255,1196 \mathrm{~cm}^{-1}$.

2-Cyano-3-(3,4,5-trimethoxy-phenyl)-propionic acid ethyl ester (4)

The reaction was carried out 2-cyano-3-(3,4,5-trimethoxy- phenyl)-acrylic acid ethyl ester (250 mg, $0.860 \mathrm{mmol})$, Hantzsch ester (240 mg, $0.950 \mathrm{mmol})$, and silica $(2.5 \mathrm{~g})$ in presence of toluene $(5 \mathrm{~mL})$ at reflex condition for $5 \mathrm{~h}$. The title compound 4 was obtained ( $275 \mathrm{mg}, 94 \%$ ). The spectral data of the compound $\mathbf{4}$ was in agreement with the values reported in the literature.

${ }^{1} \mathrm{H}$ NMR $\left(400 \mathrm{MHz}, \mathrm{CDCl}_{3}\right) \delta 1.22(\mathrm{t}, J=7.2 \mathrm{~Hz}, 3 \mathrm{H}$, $\left.-\mathrm{CH}_{2} \mathrm{CH}_{3}\right), 3.12\left(\mathrm{~m}, J=5.6,13.6 \mathrm{~Hz}, 2 \mathrm{H}, \mathrm{Ar}_{-} \mathrm{CH}_{2}\right), 3.64$ (t, $\left.J=5.6,1 \mathrm{H}, \mathrm{ArCH}_{2}-\mathrm{CH}-\right), 3.76\left(\mathrm{~s}, 3 \mathrm{H},-\mathrm{OCH}_{3}\right), 3.78(\mathrm{~s}, 6 \mathrm{H}$, 2- $\mathrm{OCH}_{3}$ ), 4.19 (q, J=7.2, 14. Hz, $\left.2 \mathrm{H},-\mathrm{CH}_{2} \mathrm{CH}_{3}\right), 6.42$ (s, 2H, ArH). IR (KBr) 2942, 2253, 1743, 1592, 1509, 1463, $1245,1127,1005,851 \mathrm{~cm}^{-1}$.

\section{2-(2-Chloro-benzylidene)-3-oxo-butyric acid ethyl ester (7d)}

The reaction was carried out according to the general procedure using 2-chloro benzaldehyde (100 $\mathrm{mg}, 0.711$ $\mathrm{mmol}$ ), ethylacetoacetate $(102 \mathrm{mg}, 0.783 \mathrm{mmol})$ and $\mathrm{Yb}(\mathrm{OTf})_{3}$ (50 mg, $0.071 \mathrm{mmol}$ ) conditions: $80-85{ }^{\circ} \mathrm{C}, 15 \mathrm{~h}$. The crude product was purified by column chromatography (silica gel, hexane: ethyl acetate. 9:1). First eluted was unreacted starting material 1d (40 mg, 40\%). Second eluted was the title compound $7 \mathbf{d}$ was obtained $(54 \mathrm{mg}$, $57 \%$, yield calculated based on the recovered starting material) as an oilic mass. The spectral data of the compound $7 \mathbf{d}$ was in agreement with the values reported in the literature.

${ }^{1} \mathrm{H}$ NMR $\left(400 \mathrm{MHz}, \mathrm{CDCl}_{3}\right) \delta 1.17(\mathrm{t}, J=7.2 \mathrm{~Hz}, 3 \mathrm{H}$, $-\mathrm{CH}_{2} \mathrm{CH}_{3}$ ), 2.42 (s, $\left.3 \mathrm{H},-\mathrm{COCH}_{3}\right), 4.24$ (q, $J=7.6,14.0 \mathrm{~Hz}$, $\left.2 \mathrm{H},-\mathrm{CH}_{2} \mathrm{CH}_{3}\right), 7.35(\mathrm{~m}, 4 \mathrm{H}, \mathrm{ArH}) .7 .85(\mathrm{~s}, 1 \mathrm{H}, \mathrm{ArCH}=)$. IR(KBr) 1724, 1669, 1618, 1468, 1439, 1376, 1239, $1200 \mathrm{~cm}^{-1}$.

\section{3-(4-Nitrobenzylidene)pentane-2,4-dione (7f)}

The reaction was carried out according to the general experimental procedure using 4-nitrobenzaldehyde (250 $\mathrm{mg}, 1.650 \mathrm{mmol})$, acetyl acetone $(182 \mathrm{mg}, 1.820 \mathrm{mmol})$ and $\mathrm{Yb}(\mathrm{OTf})_{3}(103 \mathrm{mg}, 0.165 \mathrm{mmol})$. Conditions: $80-85^{\circ} \mathrm{C}$, $18 \mathrm{~h}$. The title compound $7 \mathbf{f}$ was obtained (131 mg, 34\%) as a clear oilic mass. The spectral data for the compound $7 \mathbf{f}$ was in agreement with the values already reported in the literature.

${ }^{1} \mathrm{H}$ NMR $\left(400 \mathrm{MHz}, \mathrm{CDCl}_{3}\right) \delta 2.23\left(\mathrm{~s}, 3 \mathrm{H},-\mathrm{COCH}_{3}\right)$, 2.39 (s, $\left.3 \mathrm{H},-\mathrm{COCH}_{3}\right), 3.76$ (s, $\left.3 \mathrm{H},-\mathrm{OCH}_{3}\right), 7.43(\mathrm{~s}, 1 \mathrm{H}$, $\mathrm{ArCH}=), 7.48$ (d, 2H, ArH), 8.17 (d, 2H, ArH). IR (KBr) 1709, 1653, 1595, 1518, 1345, 1237, 1172, $858 \mathrm{~cm}^{-1}$.

\section{5-(4-Hydroxy-3-methoxybenzylidene)pyrimidine-2,4,6 (1H,3H,5H)-trione (13c)}

The reaction was carried out according to the general 
experimental procedure using vaniline $(250 \mathrm{mg}, 1.645 \mathrm{mmol})$, barbituric acid $(210 \mathrm{mg}, 1.645 \mathrm{mmol})$ and $\mathrm{Yb}(\mathrm{OTf})_{3}(102$ $\mathrm{mg}, 0.165 \mathrm{mmol})$. Conditions: $80-85^{\circ} \mathrm{C}, 5 \mathrm{~h}$. The title compound $13 \mathrm{c}$ was obtained (415 $\mathrm{mg}, 96 \%$ ) as a solid, $\mathrm{mp}$ $309-311^{\circ} \mathrm{C}$. The spectral data for the compound $13 \mathrm{c}$ was in agreement with the values already reported in the literature.

${ }^{1} \mathrm{H}$ NMR (400 MHz, DMSO) $\delta 3.82\left(\mathrm{~s}, 3 \mathrm{H},-\mathrm{OCH}_{3}\right)$, 6.89 (d, 1H, ArH), 7.79 (m, 1H, ArH), 8.21 (s, 1H, ArCH=), 8.47 (d, 1H, ArH), 10.56 (s, 1H, -OH), 11.13 (s, 1H, -NH), 11.26 (s, 1H, -NH). IR (KBr) 3456, 3195, 3130, 3052, 2847, 1729, 1692, 1657, 1542, 1498, 1398, 1299, 1273, $1255,1178,1136,1024,851,791,516 \mathrm{~cm}^{-1}$.

\section{2,2-Dimethyl-5-(4-methoxybenzylidene)-1,3-diox- ane-4,6-dione (14b)}<smiles>COc1ccc(C=C2C(=O)OC(C)(C)OC2=O)cc1</smiles>

The reaction was carried out according to the general experimental procedure using 4-methoxybenzaldehyde (250 $\mathrm{mg}, 1.836 \mathrm{mmol}$ ), meldrumsacid (317 mg, $2.201 \mathrm{mmol}$ ) and $\mathrm{Yb}(\mathrm{OTf})_{3}(115 \mathrm{mg}, 0.185 \mathrm{mmol})$. Conditions: $80-85^{\circ} \mathrm{C}$, $4.5 \mathrm{~h}$. The title compound $\mathbf{1 4 b}$ was obtained $(320 \mathrm{mg}$, $67 \%$ ) as a solid, mp $127-129^{\circ} \mathrm{C}$. The spectral data for the compound 14b was in agreement with the values already reported in the literature.

${ }^{1} \mathrm{H}$ NMR (400 MHz, DMSO) $\delta 1.72\left(\mathrm{~s}, 6 \mathrm{H},-\mathrm{CH}_{3}\right), 3.87$ (s, 3H, $\left.-\mathrm{OCH}_{3}\right) 7.09$ (d, 2H, ArH), 8.22 (d, 2H, ArH), 8.30 (s, $1 \mathrm{H}, \mathrm{ArCH}=$ ).

IR (KBr) 3101, 2997, 2840, 1747, 1714, 1574, 1514, 1429, 1391, 1203, 1171, 1019, 933, 837, $798 \mathrm{~cm}^{-1}$.

Acknowledgments. Council of Scientific and Industrial Research (CSIR), New Delhi is gratefully acknowledged for financial support (Grant No.: 80(0067)/07/EMRII, dt. 02-11-2007) and Senior Research Fellowship to SM. We are grateful to the DST-FIST for the use of $400 \mathrm{MHz}$ NMR facility at the School of Chemistry, Bharathidasan University.

\section{REFERENCES}

1. Kraus, G. A.; Krolski, M. E. Therapeutic drugs. J. Org. Chem. 1986, 51, 3347.

2. Tietze, L. F. Natural products. Pure Appl. Chem. 2004, 76, 1967

3. Liang, F.; Pu, Y.; Kurata, T.; Kido, J.; Nishide, H. Her- bicides, insecticides, functional polymers. Polymer. 2005, 46, 3767.

4. Zahouily, M.; Salah, M.; Bahlaouane, B.; Rayadh, A.; Houmam, A.; Hamed, E.A.; Sebti, S. Fine chemicals. Tetrahedron 2004, 60, 1631.

5. Knoevenagel, E. Bertt. 1898, 31, 2585.

6. Jones, G. Org. React. 1967, 15, 204.

7. Bose, D. S.; Narsaiah, A. V. J. Chem. Res. 2001, Suppl. 1,36 .

8. Narsaiah, A. V.; Basak, A. K.; Visali, B.; Nagaiah, K. Synth. Commun. 2004, 16, 2893.

9. Cardilla, G.; Fabbroni, S.; Luca, G.; Massimo, G.; Tolomelli, A. Synth. Commun. 2003, 9, 1587.

10. Abdallah, S.; Ayoubi, E. I.; Texir - Baullet, F. J.; Hamelin, J. Synthesis 1994, 258.

11. Acker, D. S.; Hertler, W. R. J. Am. Chem. Soc. 1962, 84, 3370.

12. Batsus, J. B. Tetrahedron Lett. 1963, 4, 955.

13. Sebti, S.; Smahi, A.; Solhy, A. Tetrahedron Lett. 2002, 43, 1813.

14. Rand, L.; Swisher, J. V.; Cronin, C. J. J. Org. Chem. 1962, 27, 3505.

15. Santamarta, F.; Verdia, P.; Tojo, E. Catal. Commun. 2008, 9, 1779.

16. Ramani, A.; Chanda, B. M.; Velu, S.; Sivasankar, S. Heterogeneous catalysts. Green Chem. 1999, 163.

17. Lu, Y.; Ren, Z.; Cao, W.; Tong, W.; Gao. M. Neutral compounds. Synth. Commun. 2004, 34, 2047.

18. Bartoli, G.; Bosco, M.; Carlone, A.; Dalpozzo, R.; Galzerano, P.; Melchiorre, P.; Sambri, L. Tetrahedron Lett. 2008, 49, 2555.

19. Saravanamurugan, S.; Palanichamy, M.; Hartmann, M.; Murugesan, V. High reaction temperatures. Appl. Catal., A, 2006, 298, 8.

20. Bigi, F.; Chesini, L.; Maggi, R.; Sartori, G. High reaction temperatures. J. Org. Chem. 1999, 64, 1033.

21. Kantevari, S.; Bantu, R.; Nagarapu, L. Microwave irradiation: High reaction temperatures. J. Mol. Catal., A: Chem. 2007, 269, 53.

22. Bigi, F.; Conforti, M. L.; Maggi, R.; Piccino, A.; Sartori, G. Green Chem. 2000, 2, 101.

23. Hangarge, R. V.; Sonwane, S. A.; Jarikote, D. V.; Shingare, M. S. Green Chem. 2001, 3, 310.

24. Kaupp, G.; Naimi-Jamal, M. R.; Schmeyers, J. Tetrahedron. 2003, 59, 3753.

25. Yadav, J. S.; Subba Reddy, B. V.; Basak, A. K.; Visali, B.; Narsaiah, A. V.; Nagaiah, K. Microwave irradiation. Eur. J. Org. Chem. 2004, 546.

26. Deb, M. L.; Bhuyan, P. J. Tetrahedron Lett. 2005, 46, 6453.

27. Jenner, G. High pressure. Tetrahedron Lett. 2001, 42, 243.

28. McNulty, J.; Steere, J. A.; Wolf, S. Ultrasound. Tetrahedron Lett. 1998, 39, 8013.

29. Narasiah, A.V.; Nagaih, K. Synth. Commun. 2003, 33, 3825 . 
30. Leelavathi, P.; Ramesh Kumar, S. J. Mol. Catal., A: Chem. 2005, 240, 99.

31. Lehnert, W. Tetrahedron 1974, 30, 301.

32. Green, B.; Crane, R. I.; Khaidem, I. S.; Leighton, R. S.; Newaz, S. S.; Smyser, T. E. J. Org. Chem. 1985, 50, 640.

33. Shanthan R. P.; Venkataratnam, R. V. Tetrahedron Lett. 1991, 32, 5821.

34. Saeed Abaee, M.; Mojtahedi, M. M.; Zahedi, M. M.; Khanalizadeh, G. ARKIVOC 2006, XV, 48.

35. March, J. Advanced Organic Chemistry, 4th ed.; John Wiley and Sons: New York, 2003; Chap. 1, p 18. and references cited therein.

36. Frontier, A. J.; Collison, C. Tetrahedron 2005, 61, 7577.

37. Malona, J. A.; Colbourne, J. M.; Frontier, A. J. Org. Lett., 2006, 8,5661 .

38. Pridgen, L. N,; Huang, K.; Shilcrat, S.; Tickner - Eldridge, A.; Debrosse, C. S.; Haltwinger, R. C., Synlett 1999, 10, 1612.

39. Cui, H.-F.; Dong, K.-Y.; Zhang, G.-W.; Wang, L.; Na, J.A. Chem. Commun. 2007, 2284.

40. Nie, J.; Zhu, H.-W.; Cui, H.-F.; Hua, M.-Q.; Ma, J.-A. Org. Lett., 2007, 16, 3053.

41. Balasubramanian, T. M.; Liu, G. K.; Kinsley, S. A.; Duck- worth, C. A.; Poteruca, J. J.; Brown, P. S.; Miller, J. L. J. Org. Chem. 1987, 52, 1017

42. Kobayashi, S.; Sugiura, M.; Kitagawa, H.; Lam, W. W. L. Chem. Rev. 2002, 102, 2227.

43. Sharma, G. V. M.; Ilangovan, A.; Mahalingam, A. K. J. Org. Chem. 1998, 63, 9103.

44. Sharma, G. V. M.; Ilangovan, A. Synlett 1999. 1963.

45. Sharma, G. V. M.; Ilangovan, A.; Sreenivas, P.; Mahalingam, A. K. Synlett 2000, 615.

46. Wang, L.-M.; Sheng, J.; Zhang, L.; Han, J.-W.; Fan, Z.Y,; Tian, H. Chinese J. Org. Chem. 2005, 25, 964.

47. Massimo, C.; Francesco, E.; Federica, M.; Ornelio, R. Synlett 2003, 4, 552.

48. Lee, Y. R.; Kweon, H. I.; Koh, W. S.; Min, K. R.; Kim, Y.; Ho, S. Synthesis 2001, 12, 1851.

49. Smal, M.; Cheung, H. T. A.; Davis, P. E. J. Chem. Soc. Perkin Trans. 1. 1986, 747.

50. Roth, B.; Falco, E. A.; Hitchings, G. H.; Bushby, S. R. M. J. Med. Pharm. Chem. 1962, 5, 1103.

51. Sebti, S.; Nazih, R.; Rahir, R.; Salhi, L.; Saber, H. Fluorapatite. Appl. Catal., A 2000, 197, L187.

52. Kumbhare, R. M.; Sridhar, M. Catal. Commun. 2008, 9, 403. 